\title{
STUDIES IN DIABETIC ACIDOSIS AND COMA, WITH PARTICULAR EMPHASIS ON THE RETENTION OF ADMINIS- TERED POTASSIUM
}

\author{
By T. S. DANOWSKI, J. H. PETERS, J. C. RATHBUN, \\ J. M. QUASHNOCK, AND L. GREENMAN \\ (From the Departments of Research Medicine and of Physiological Chemistry, the Children's \\ and Presbyterian Hospitals, and the Renziehausen Foundation, University of \\ Pittsburgh, School of Medicine, Pittsburgh)
}

(Received for publication July 22, 1948)

Abnormally low concentrations of potassium, at times associated with muscular paralysis, have been observed in the serum of diabetic patients while under treatment for acidosis or coma (1-4). Available data indicate that deficits of cell potassium are also present in at least some of these subjects (5). In an attempt to characterize and quantitate the magnitude of these deficits, exchanges of water, electrolytes, carbohydrate, and protein have been investigated in diabetic acidosis and coma prior to, during, and following the administration of potassium salts.

\section{EXPERIMENTAL PROCEDURE AND METHODS}

Eight cases in all have been studied. Of these, two were adults and the remaining six juvenile diabetics 16 years of age or younger. On admission all had Kussmaul breathing, a marked reduction of the serum bicarbonate content, hyperglycemia, glycosuria, and ketonuria.

Studies during treatment and recovery were divided into three periods. The first or pre- $\mathrm{KCl}$ period extended from admission to the point where the patients had improved sufficiently to be maintained on an oral intake. During this time insulin, 0.9 per cent saline, and, once the blood sugar began to drop, glucose solutions were administered in amounts summarized in Table I. Under this treatment ketosis diminished, overbreathing ceased, hyperglycemia decreased, and mental clarity returned. This interval lasted 12 to 25 hours in the individual subjects. During the second or $\mathrm{KCl}$ period, 22 to 37 hours in length, the patients received insulin, 10.0 to 30.0 grams of $\mathrm{KCl}$ per os or intravenously, whole milk containing added carbohydrate, and water as desired. The third or post- $\mathrm{KCl}$ period began after the final dose of $\mathrm{KCl}$ and lasted up to 34 hours. During this time the patients received insulin as needed, together with measured amounts of water and milk.

In all subjects concentrations of the whole blood nonprotein nitrogen, blood sugar (6-8), and the levels of serum chloride, bicarbonate, sodium, potassium and water were measured at the beginning and end of each period $(6,9-12)$. Average values for the electrolyte, carbo- hydrate, and protein content of fresh milk have been used in calculating the intake $(13,14)$. Urine excreted during each period was analyzed for nitrogen, sodium, potassium, chloride, and glucose $(6,10,11,15,16)$. Body weight was determined when possible at the start and end of each period.

\section{METHOD OF CALCULATION}

Alterations in extracellular fluid volume were calculated from changes in the chloride space, based on the external balance of this anion and corrected for changes in the serum concentrations of chloride as described by Elkinton and co-workers, and by Darrow (17-19). In view of the dehydration known to develop in the course of diabetic acidosis and coma, the initial extracellular volume was assumed for purposes of this calculation to be 15 per cent of the body weight rather than the usual value of 18.7 to 23 per cent found in non-dehydrated human subjects (20). In two instances a pre-treatment weight could not be obtained. A reasonable assumption was therefore made as to its magnitude, based upon subsequent weights and the balance of water. The volume of the chloride space and the concentrations of sodium and potassium in extracellular water, corrected for the Donnan effect, were used in the calculation of increments and decrements of these ions in extracellular fluid. The retention of sodium and of potassium by cells was taken to be the difference between the intake of these cations and the amounts retained in excellular fluid plus those excreted in urine. In the case of potassium the final values recorded include corrections for the balance of cellular nitrogen, using the $\mathrm{K}: \mathrm{N}$ ratio of 2.38 m.eq.: 1.0 gm. N. In determining the balance of cellular nitrogen, changes in the concentration of the nonprotein nitrogen have been taken into account, assuming for this purpose that the nonprotein nitrogen is distributed uniformly through all of the body water, and that 0.65 of the body weight is water. Similar treatment of the sodium data does not, of course, significantly affect the balances of this electrolyte because of the low $\mathrm{Na}: \mathrm{N}$ ratio in cells. The data on cell base in Table III represent, therefore, balances in excess of the sodium and potassium which move with nitrogen in the anabolism and catabolism of protein. 
TABLE I

Intake and output during therapy of diabetic acidosis and coma

\begin{tabular}{|c|c|c|c|c|c|c|c|c|c|c|c|c|c|c|}
\hline \multirow{2}{*}{ Pt. } & \multirow{2}{*}{ Period } & \multicolumn{7}{|c|}{ Intake } & \multicolumn{6}{|c|}{ Urine output } \\
\hline & & Insulin & $\mathrm{H}_{2} \mathrm{O}$ & $\mathrm{Cl}$ & $\mathrm{Na}$ & $\mathbf{K}$ & $\mathbf{N}$ & $\mathrm{CHO}$ & Vol. & $\mathrm{Cl}$. & $\mathrm{Na}$ & $\mathbf{K}$ & $\mathbf{N}$ & Glucose \\
\hline T.W. & $\begin{array}{r}\text { I } \\
\text { II } \\
\text { III }\end{array}$ & $\begin{array}{r}\text { units } \\
650 \\
135 \\
75\end{array}$ & \begin{tabular}{|c|}
$m l$. \\
13,335 \\
3,333 \\
2,150
\end{tabular} & $\begin{array}{r}\text { m. eq. } \\
1,723 \\
629 \\
71\end{array}$ & $\begin{array}{r}\text { m. eq. } \\
1,723 \\
212 \\
57\end{array}$ & $\begin{array}{r}\text { m. eq. } \\
49 \\
490 \\
85\end{array}$ & $\begin{array}{r}\text { gms. } \\
0 \\
12.1 \\
11.8\end{array}$ & $\begin{array}{l}g m s . \\
300 \\
270 \\
268\end{array}$ & $\begin{array}{c}m l . \\
1,675 \\
1,180 \\
2,300\end{array}$ & $\begin{array}{c}\text { m. eq. } \\
178 \\
192 \\
442\end{array}$ & $\begin{array}{c}\text { m. eq. } \\
92 \\
85 \\
262\end{array}$ & $\begin{array}{c}\text { m. eq. } \\
37 \\
39 \\
90\end{array}$ & $\begin{array}{r}\text { gms. } \\
7.6 \\
7.3 \\
10.5\end{array}$ & $\begin{array}{l}11 \\
13 \\
27\end{array}$ \\
\hline M.S. & $\begin{array}{r}\text { I } \\
\text { II } \\
\text { III }\end{array}$ & $\begin{array}{r}170 \\
5 \\
20\end{array}$ & $\begin{array}{l}6,255 \\
3,075 \\
1,025\end{array}$ & $\begin{array}{r}726 \\
182 \\
34\end{array}$ & $\begin{array}{r}726 \\
38 \\
29\end{array}$ & $\begin{array}{r}8 \\
192 \\
42\end{array}$ & $\begin{array}{l}0.6 \\
8.0 \\
6.8\end{array}$ & $\begin{array}{r}132 \\
74 \\
43\end{array}$ & $\begin{array}{r}1,663 \\
2,190 \\
970\end{array}$ & $\begin{array}{r}79 \\
279 \\
121\end{array}$ & $\begin{array}{r}38 \\
133 \\
92\end{array}$ & $\begin{array}{l}55 \\
83 \\
20\end{array}$ & $\begin{array}{r}10.9 \\
10.4 \\
5.8\end{array}$ & $\begin{array}{r}24 \\
0 \\
0\end{array}$ \\
\hline J.K. & II & $\begin{array}{r}240 \\
120 \\
15\end{array}$ & $\begin{array}{r}5,240 \\
5,275 \\
800\end{array}$ & $\begin{array}{r}769 \\
488 \\
20\end{array}$ & $\begin{array}{r}769 \\
69 \\
16\end{array}$ & $\begin{array}{r}0 \\
505 \\
24\end{array}$ & $\begin{array}{r}0 \\
14.2 \\
3.3\end{array}$ & $\begin{array}{r}132 \\
343 \\
98\end{array}$ & $\begin{array}{r}3,490 \\
4,050 \\
315\end{array}$ & $\begin{array}{r}257 \\
523 \\
33\end{array}$ & $\begin{array}{r}265 \\
187 \\
10\end{array}$ & $\begin{array}{r}74 \\
208 \\
16\end{array}$ & $\begin{array}{r}8.6 \\
11.1 \\
1.2\end{array}$ & $\begin{array}{r}155 \\
65 \\
14\end{array}$ \\
\hline W.S. & $\begin{array}{c}\text { I } \\
\text { II } \\
\text { III }\end{array}$ & $\begin{array}{r}154 \\
0 \\
58\end{array}$ & $\begin{array}{l}4,000 \\
4,350 \\
1,550\end{array}$ & $\begin{array}{r}615 \\
303 \\
51\end{array}$ & $\begin{array}{r}615 \\
289 \\
41\end{array}$ & $\begin{array}{r}0 \\
322 \\
61\end{array}$ & $\begin{array}{r}0 \\
12.0 \\
8.5\end{array}$ & $\begin{array}{r}75 \\
155 \\
74\end{array}$ & $\begin{array}{l}1,100 \\
4,200 \\
2,136\end{array}$ & $\begin{array}{r}165 \\
718 \\
33\end{array}$ & $\begin{array}{l}116 \\
421 \\
207\end{array}$ & $\begin{array}{r}53 \\
183 \\
60\end{array}$ & $\begin{array}{l}6.1 \\
4.8 \\
8.4\end{array}$ & $\begin{array}{l}26 \\
59 \\
22\end{array}$ \\
\hline L.D. & $\begin{array}{r}\text { I } \\
\text { II } \\
\text { III }\end{array}$ & $\begin{array}{r}280 \\
20 \\
70\end{array}$ & $\begin{array}{l}6,570 \\
5,510 \\
4,525\end{array}$ & $\begin{array}{l}775 \\
457 \\
131\end{array}$ & $\begin{array}{l}775 \\
170 \\
106\end{array}$ & $\begin{array}{c}0 \\
380^{0} \\
158\end{array}$ & $\begin{array}{r}0 \\
15.9 \\
21.9\end{array}$ & $\begin{array}{l}143 \\
138 \\
190\end{array}$ & $\begin{array}{l}4,330 \\
2,800 \\
4,510\end{array}$ & $\begin{array}{l}566 \\
306 \\
409\end{array}$ & $\begin{array}{l}473 \\
106 \\
232\end{array}$ & $\begin{array}{l}65 \\
36 \\
51\end{array}$ & $\begin{array}{r}7.1 \\
6.1 \\
11.7\end{array}$ & $\begin{array}{r}67 \\
5 \\
2\end{array}$ \\
\hline R.J. & $\begin{array}{r}\text { I } \\
\text { II } \\
\text { III }\end{array}$ & $\begin{array}{r}500 \\
105 \\
50\end{array}$ & $\begin{array}{l}6,750 \\
4,800 \\
2,500\end{array}$ & $\begin{array}{r}998 \\
288 \\
16\end{array}$ & $\begin{array}{r}1,025 \\
16 \\
13\end{array}$ & $\begin{array}{r}3 \\
292 \\
20\end{array}$ & $\begin{array}{l}8.4 \\
3.8 \\
2.7\end{array}$ & $\begin{array}{r}115 \\
29 \\
24\end{array}$ & $\begin{array}{r}1,775 \\
818 \\
1,790\end{array}$ & $\begin{array}{l}139 \\
133 \\
249\end{array}$ & $\begin{array}{r}106 \\
78 \\
146\end{array}$ & $\begin{array}{l}28 \\
30 \\
45\end{array}$ & $\begin{array}{r}10.0 \\
9.8 \\
12.7\end{array}$ & $\begin{array}{r}39 \\
1 \\
45\end{array}$ \\
\hline D.C.(a) & $\begin{array}{r}\text { I } \\
\text { III }\end{array}$ & $\begin{array}{r}245 \\
105 \\
57\end{array}$ & $\begin{array}{l}6,876 \\
2,550 \\
3,200\end{array}$ & $\begin{array}{r}1,020 \\
475 \\
105\end{array}$ & \begin{tabular}{|r}
1,020 \\
58 \\
85
\end{tabular} & $\begin{array}{r}0 \\
490 \\
126\end{array}$ & $\begin{array}{r}0 \\
12.0 \\
17.5\end{array}$ & $\begin{array}{l}127 \\
105 \\
152\end{array}$ & \begin{tabular}{|l}
3,630 \\
6,580 \\
2,000
\end{tabular} & $\begin{array}{l}355 \\
990 \\
168\end{array}$ & $\begin{array}{r}275 \\
584 \\
16\end{array}$ & $\begin{array}{r}105 \\
251 \\
88\end{array}$ & $\begin{array}{l}14.1 \\
21.7 \\
16.6\end{array}$ & $\begin{array}{r}70 \\
167 \\
83\end{array}$ \\
\hline D.C.(b) & $\begin{array}{r}\text { I } \\
\text { II } \\
\text { III }\end{array}$ & $\begin{array}{r}230 \\
90 \\
70\end{array}$ & $\begin{array}{l}6,925 \\
6,135 \\
3,175\end{array}$ & $\begin{array}{r}973 \\
495 \\
75\end{array}$ & $\begin{array}{r}973 \\
90 \\
61\end{array}$ & $\begin{array}{r}0 \\
518 \\
91\end{array}$ & $\begin{array}{r}0 \\
18.5 \\
12.6\end{array}$ & $\begin{array}{l}275 \\
404 \\
185\end{array}$ & \begin{tabular}{|l}
4,250 \\
6,710 \\
1,770
\end{tabular} & $\begin{array}{r}73 \\
846 \\
72\end{array}$ & $\begin{array}{r}164 \\
475 \\
24\end{array}$ & $\begin{array}{r}124 \\
233 \\
60\end{array}$ & $\begin{array}{r}5.4 \\
15.7 \\
7.9\end{array}$ & $\begin{array}{r}129 \\
268 \\
60\end{array}$ \\
\hline
\end{tabular}

\section{RESULTS}

\section{A. Alteration in serum water and in extracellular volume}

On admission a variable degree of plasma dehydration, as measured by the water content, was present (Table II). The values ranged from 897 to 924 gms. of water per liter of serum in contrast to levels of 922 to 938 gms. per liter ordinarily found in healthy adults (21). There is no means of deciding how much of the deficit in any particular patient should be assigned to losses of body fluid alone, and how much is to be considered secondary to a disappearance of circulating plasma proteins of the type observed during depletion of body water and solutes $(22,23)$. At the end of the first period of treatment all serum water values were again in the normal range, or actually above it. No consistent pattern is apparent in the fluctuations in serum water during the second and third treatment periods.

The expansion in the chloride space uniformly observed in each patient at the end of the first treatment period suggests that considerable deficits of extracellular water as well had been incurred prior to admission (Table III). These increments, as calculated from the chloride space, ranged from +1.0 to +9.5 liters. Since subsequent changes in Periods II and III of each study in no instance entirely cancelled this initial expansion it is reasonable to interpret this persistent positive balance of extracellular water as indirect evidence suggestive of extracellular dehydration on admission. On the other hand, it is likely that in at least some of the subjects the extracellular fluid volume had been overexpanded, even though edema did not develop. This appeared to be true in some of the infants with diarrhea treated by Darrow (19).

\section{B. Serum electrolyte concentrations prior to and during therapy}

1. Sodium and chloride: Despite these deficits of body water it is to be noted that the concen- 
trations of sodium and chloride, the chief electrolytes of extracellular fluid and serum, were not increased above the usual range of isotonicity (Table II, at zero point of Period I). As a matter of fact, the concentrations of sodium were abnormally low in five patients. In all of these and in one other the concentrations of chloride in serum, taking 97 m.eq. per liter as the lower limit of normal, were also decreased (24). In view of the dehydration described above, it is immediately apparent that these patients had lost, in keeping with the findings in other series, considerable amounts of the chief extracellular electrolytes, con- comitant with, and in most instances, in excess of, the losses of body water $(25,26)$. Had water alone been lost, the levels of sodium and chloride would have been increased above normal.

During the first period of treatment in which 0.9 per cent saline solution was given, the concentrations of sodium and of chloride rose in all patients (Table II, end of Period I). As a matter of fact in all but one instance, patient J. K., definite hypernatremia and hyperchloremia appeared. In subject R. J., for example, who started with normal concentrations, the sodium in serum increased to 161.6 m.eq. per liter and the chloride

TABLE II

Body weight and analyses of blood and serum during treatment of diabetic acidosis and coma

\begin{tabular}{|c|c|c|c|c|c|c|c|c|c|c|}
\hline \multirow{2}{*}{$\underset{(\text { age-sex })}{\text { Patient }}$} & \multirow{2}{*}{ Period } & \multirow{2}{*}{$\begin{array}{c}\text { Time from } \\
\text { start }\end{array}$} & \multirow{2}{*}{$\begin{array}{l}\text { Body* } \\
\text { wgt. }\end{array}$} & \multicolumn{2}{|c|}{ Blood* } & \multicolumn{5}{|c|}{ Serum* } \\
\hline & & & & NPN & Sugar & $\mathrm{HCO}_{3}$ & $\mathrm{Cl}$ & $\mathrm{Na}$ & $\mathbf{K}$ & $\mathrm{H}_{2} \mathrm{O}$ \\
\hline $\begin{array}{l}\text { T.W. } \\
(26 \mathrm{~F})\end{array}$ & $\begin{array}{l}\text { I pre-KCl } \\
\text { II } \mathrm{KCl} \text { p.o. } \\
\text { III post-KCl }\end{array}$ & $\begin{array}{r}\text { hours } \\
0 \\
0-25 \\
25-48 \\
48-70\end{array}$ & $\begin{array}{l}\text { kgm. } \\
60.8\end{array}$ & $\begin{array}{c}\text { mgm. \% } \\
\text { - } \dagger \\
40 \\
37 \\
34\end{array}$ & $\begin{array}{c}\text { mgm. \% } \\
572 \\
112 \\
- \\
-\end{array}$ & \begin{tabular}{|c|} 
m. eq. $/$ liter \\
5.5 \\
11.8 \\
\\
16.4
\end{tabular} & \begin{tabular}{|c|} 
m. eq. $/$ liter \\
101.9 \\
127.8 \\
124.9 \\
110.2
\end{tabular} & \begin{tabular}{c|} 
m. eq./liter \\
142.3 \\
157.6 \\
153.1 \\
144.1
\end{tabular} & \begin{tabular}{|c|} 
m. eq./liter \\
4.0 \\
2.8 \\
5.6 \\
5.4
\end{tabular} & $\begin{array}{c}\text { grams/liter } \\
-\ddagger \\
951 \\
948 \\
944\end{array}$ \\
\hline $\begin{array}{l}\text { M.S. } \\
\text { (15F) }\end{array}$ & $\begin{array}{l}\text { I pre-KCl } \\
\text { II } \mathrm{KCl} \text {.o. } \\
\text { III post-KCl }\end{array}$ & $\begin{array}{r}0 \\
0-17 \\
17-39 \\
39-61\end{array}$ & 41.5 & $\begin{array}{l}65 \\
36 \\
26 \\
26\end{array}$ & $\begin{array}{l}667 \\
104 \\
139 \\
\cdot 259\end{array}$ & $\begin{array}{r}9.3 \\
17.4 \\
24.0 \\
23.4\end{array}$ & $\begin{array}{r}77.6 \\
107.7 \\
109.8 \\
102.8\end{array}$ & $\begin{array}{l}118.6 \\
144.6 \\
143.2 \\
144.8\end{array}$ & $\begin{array}{l}3.4 \\
3.9 \\
5.4 \\
5.6\end{array}$ & $\begin{array}{l}897 \\
943 \\
943 \\
937\end{array}$ \\
\hline$\underset{(18 F)}{J . K .}$ & $\begin{array}{l}\text { I pre-KCl } \\
\text { II } \mathrm{KCl} \text { p.o. } \\
\text { III post-KCl }\end{array}$ & $\begin{array}{r}0 \\
0-20 \\
20-67 \\
67-72\end{array}$ & $\begin{array}{l}50.0 \\
53.9 \\
53.4 \\
53.4\end{array}$ & $\begin{array}{l}32 \\
21 \\
27 \\
33\end{array}$ & $\begin{array}{l}600 \\
145 \\
235 \\
302\end{array}$ & $\begin{array}{r}8.1 \\
19.0 \\
23.4 \\
22.7\end{array}$ & $\begin{array}{l}94.1 \\
97.8 \\
98.8 \\
98.1\end{array}$ & $\begin{array}{l}135.5 \\
140.5 \\
144.4 \\
137.8\end{array}$ & $\begin{array}{l}5.4 \\
5.0 \\
5.4 \\
6.0\end{array}$ & $\begin{array}{l}916 \\
934 \\
930 \\
932\end{array}$ \\
\hline $\begin{array}{l}\text { W.S. } \\
\text { (14M) }\end{array}$ & $\begin{array}{l}\text { I pre-KCl } \\
\text { II } \mathrm{KCl} \text { p.o. } \\
\text { III post-KCl }\end{array}$ & $\begin{array}{r}0 \\
0-12 \\
12-44 \\
44-68\end{array}$ & $\begin{array}{l}36.2 \\
38.1\end{array}$ & $\begin{array}{l}39 \\
21 \\
27 \\
30\end{array}$ & $\begin{array}{r}470 \\
70 \\
362 \\
181\end{array}$ & $\begin{array}{r}6.7 \\
14.7 \\
22.4 \\
27.2\end{array}$ & $\begin{array}{r}96.3 \\
114.9 \\
98.9 \\
94.4\end{array}$ & $\begin{array}{l}129.9 \\
149.6 \\
144.8 \\
151.2\end{array}$ & $\begin{array}{l}5.5 \\
4.1 \\
5.5 \\
4.4\end{array}$ & $\begin{array}{l}912 \\
943 \\
933 \\
930\end{array}$ \\
\hline $\begin{array}{l}\text { L.D. } \\
\text { (15M) }\end{array}$ & $\begin{array}{l}\text { I pre-KCl } \\
\text { II } \mathrm{KCl} \text { p.o. } \\
\text { III post-KCl }\end{array}$ & $\begin{array}{r}0 \\
0-23 \\
23-41 \\
41-65\end{array}$ & $\begin{array}{l}38.7 \\
38.3 \\
40.9 \\
38.4\end{array}$ & $\begin{array}{l}33 \\
24 \\
28 \\
35\end{array}$ & $\begin{array}{r}1189 \\
51 \\
328 \\
352\end{array}$ & $\begin{array}{r}4.1 \\
11.2 \\
15.7 \\
24.0\end{array}$ & $\begin{array}{r}96.5 \\
109.3 \\
101.8 \\
98.0\end{array}$ & $\begin{array}{l}124.2 \\
143.9 \\
137.3 \\
142.5\end{array}$ & $\begin{array}{l}4.0 \\
1.8 \\
3.6 \\
3.0\end{array}$ & $\begin{array}{l}924 \\
943 \\
948 \\
945\end{array}$ \\
\hline $\begin{array}{l}\text { R.J.J } \\
(14 \mathrm{M})\end{array}$ & $\begin{array}{l}\text { I pre-KCl } \\
\text { II } \mathrm{KCl} \text { p.o. } \\
\text { III post-KCl }\end{array}$ & $\begin{array}{r}0 \\
0-19 \\
19-44 \\
44-68\end{array}$ & $\begin{array}{l}34.9 \\
47.2\end{array}$ & $\begin{array}{c}103 \\
79 \\
498 \\
418\end{array}$ & $\begin{array}{r}1395 \\
230 \\
118 \\
288\end{array}$ & $\begin{array}{l}10.4 \\
20.6 \\
21.3 \\
25.4\end{array}$ & $\begin{array}{l}101.9 \\
137.3 \\
123.5 \\
108.9\end{array}$ & $\begin{array}{l}142.1 \\
161.6 \\
143.9 \\
133.5\end{array}$ & $\begin{array}{l}3.7 \\
2.0 \\
4.1 \\
3.8\end{array}$ & $\begin{array}{l}912 \\
933 \\
949 \\
945\end{array}$ \\
\hline$\underset{(16 \mathrm{~F})}{\text { D.C.(a) }}$ & $\begin{array}{l}\text { I pre-KCl } \\
\text { II } \mathrm{KCl} \text { p.o. } \\
\text { III post-KCl }\end{array}$ & $\begin{array}{r}0 \\
0-23 \\
23-59 \\
59-83\end{array}$ & $\begin{array}{l}52.7 \\
53.4 \\
52.8 \\
54.0\end{array}$ & $\begin{array}{l}65 \\
28 \\
32 \\
37\end{array}$ & $\begin{array}{l}582 \\
171 \\
140 \\
167\end{array}$ & $\begin{array}{r}4.8 \\
15.1 \\
26.9 \\
29.2\end{array}$ & $\begin{array}{r}89.9 \\
111.5 \\
95.5 \\
98.1\end{array}$ & $\begin{array}{l}122.7 \\
155.9 \\
133.2 \\
139.1\end{array}$ & $\begin{array}{l}6.5 \\
3.0 \\
4.3 \\
4.1\end{array}$ & $\begin{array}{l}899 \\
941 \\
926 \\
925\end{array}$ \\
\hline$\underset{(16 \mathrm{~F})}{\text { D.C.(b) }}$ & $\begin{array}{l}\text { I pre-KCl } \\
\text { II } \mathrm{KCl} \text { i.v. } \\
\text { III post-KCl }\end{array}$ & $\begin{array}{r}0 \\
0-19 \\
19-51 \\
51-84\end{array}$ & $\begin{array}{l}50.0 \\
53.9 \\
50.9 \\
50.9\end{array}$ & $\begin{array}{l}67 \\
28 \\
29 \\
34\end{array}$ & $\begin{array}{r}786 \\
163 \\
149 \\
55\end{array}$ & $\begin{array}{r}6.8 \\
15.4 \\
26.1 \\
28.7\end{array}$ & $\begin{array}{r}91.4 \\
117.1 \\
92.1 \\
94.1\end{array}$ & $\begin{array}{l}125.3 \\
145.6 \\
140.8 \\
141.0\end{array}$ & $\begin{array}{l}6.7 \\
3.3 \\
5.7 \\
4.7\end{array}$ & $\begin{array}{l}907 \\
936 \\
949 \\
927\end{array}$ \\
\hline
\end{tabular}

* Values as recorded refer to body weight, blood, or serum observed on admission (0 hour), and at the end of each individual period.

t Assumed to be 60 for purposes of calculating balances of cell nitrogen.

$\ddagger$ Not obtained. Average value of the seven other cases used in calculating concentrations in extracellular water, 910 .

NPN drawn before end of period; lower value therefore assumed in calculations. 
to 137.3 , levels about 20 and 35 m.eq., respectively, above the usual range in healthy adults. There was no clinical evidence that this hypertonicity was in any way deleterious. The findings do suggest, however, that in most instances a less concentrated saline solution could have been used, or that the patient should have received larger quantities of glucose solution. During the $\mathrm{KCl}$ period, and subsequently, the serum chloride tended to return to, or even below, physiological concentrations. The serum sodium levels during Periods II and III in general showed a similar trend, but in no instance, in contrast to the chloride ion, did hyponatremia appear.

2. Bicarbonate: The markedly lowered concentrations of serum bicarbonate present on admission rose toward or to normal during therapy in all patients. The development of hyperchloremia, which was as has already been noted an almost invariable occurrence, did not prevent these increases in bicarbonate. However, it is not possible to answer unequivocally from these data the question as to whether or not hyperchloremia repressed the rise of serum bicarbonate. It is clear, for example, that the increase during the first period in serum bicarbonate level of 10.9 m.eq. per liter in 20 hours in patient $\mathrm{J}$. K. who did not develop hyperchloremia is quite comparable to the 10.2 m.eq. per liter increase in 19 hours in the patient with the most pronounced hyperchloremia (R. J.). On the other hand, the possibility that hyperchloremia prolonged the acidosis in patient $T$. W. can by no means be excluded. At 70 hours the bicarbonate concentration was still only

TABLE III

Balances of electrolytes, nitrogen, and carbohydrate during treatment of diabetic acidosis and coma*

\begin{tabular}{|c|c|c|c|c|c|c|c|c|c|c|c|c|}
\hline \multirow{2}{*}{ Pt. } & \multirow{2}{*}{ Period } & \multicolumn{5}{|c|}{ External balance } & \multicolumn{3}{|c|}{ Extracellular balance } & \multicolumn{3}{|c|}{ Intracellular balanceł } \\
\hline & & $\mathrm{Cl}$ & $\mathrm{Na}$ & $\mathbf{K}$ & $\mathbf{N}$ & сно & Fluid & $\mathrm{Na}$ & $\mathbf{K}$ & $\mathbf{N}$ & $\mathrm{Na}$ & $\mathbf{K}$ \\
\hline T.W. & $\begin{array}{r}\text { I } \\
\text { III }\end{array}$ & $\begin{array}{c}\text { m. eq. } \\
+1533 \\
+434 \\
-375\end{array}$ & $\begin{array}{c}\text { m.eq. } \\
+1616 \\
+124 \\
-209\end{array}$ & $\begin{array}{l}m . e q . \\
+\quad 11 \\
+450 \\
-\quad 5\end{array}$ & $\begin{array}{c}\text { gms. } \\
-7.6 \\
+4.7 \\
+1.2\end{array}$ & $\begin{array}{l}\text { gms. } \\
+289 \\
+257 \\
+240\end{array}$ & $\begin{array}{l}\text { liters } \\
+9.5 \\
+3.5 \\
-0.3\end{array}$ & $\begin{array}{c}\text { m.eq. } \\
+1561 \\
+463 \\
-228\end{array}$ & $\begin{array}{l}m . e q . \\
+15 \\
+69 \\
-6\end{array}$ & $\begin{array}{c}\text { gms. } \\
-0.5 \\
+\quad 5.8 \\
+2.3\end{array}$ & $\begin{array}{l}m . \text { eq. } \\
+56 \\
-339 \\
+\quad 19\end{array}$ & $\begin{array}{l}\text { m. eq. } \\
-\quad 3 \\
+367 \\
-\quad 5\end{array}$ \\
\hline M.S. & $\begin{array}{r}\text { I } \\
\text { II } \\
\text { III }\end{array}$ & $\begin{array}{r}+638 \\
-\quad 102 \\
-\quad 90\end{array}$ & $\begin{array}{rr}+ & 674 \\
- & 101 \\
- & 68\end{array}$ & $\begin{array}{l}-48 \\
+108 \\
+\quad 22\end{array}$ & $\begin{array}{r}-10.4 \\
-\quad 2.5 \\
+\quad 1.0\end{array}$ & $\begin{array}{l}+108 \\
+74 \\
+43\end{array}$ & $\begin{array}{l}+3.7 \\
-1.0 \\
-0.2\end{array}$ & $\begin{array}{r}672 \\
+\quad 165 \\
-\quad 6\end{array}$ & $\begin{array}{l}+17 \\
+10 \\
+1\end{array}$ & $\begin{array}{r}2.6 \\
+\quad 0.2 \\
+\quad 1.0\end{array}$ & $\begin{array}{l}+\quad 2 \\
-64 \\
-62\end{array}$ & $\begin{array}{l}-59 \\
+98 \\
+\quad 19\end{array}$ \\
\hline J.K. & $\begin{array}{r}\text { I } \\
\text { II } \\
\text { III }\end{array}$ & $\begin{array}{r}+503 \\
-\quad 38 \\
-\quad 16\end{array}$ & $\begin{array}{rr}+ & 491 \\
- & 122 \\
+ & 2\end{array}$ & $\begin{array}{r}-75 \\
+297 \\
+\quad 8\end{array}$ & $\begin{array}{r}-8.6 \\
+\quad 3.1 \\
+\quad 2.1\end{array}$ & $\begin{array}{l}-16 \\
+278 \\
+84\end{array}$ & $\begin{array}{r}+4.4 \\
-0.5 \\
0\end{array}$ & $\begin{array}{r}650 \\
-\quad 20 \\
+\quad 86\end{array}$ & $\begin{array}{l}+19 \\
+2 \\
+8\end{array}$ & $\begin{array}{r}5.0 \\
+\quad 1.2 \\
+\quad 0.2\end{array}$ & $\begin{array}{l}+159 \\
-102 \\
-\quad 88\end{array}$ & $\begin{array}{r}-82 \\
+292 \\
0\end{array}$ \\
\hline W.S. & II & $\begin{array}{r}+443 \\
-\quad 418 \\
+\quad 15\end{array}$ & $\begin{array}{r}+489 \\
-136 \\
-170\end{array}$ & $\begin{array}{r}-53 \\
+139 \\
+\quad 1\end{array}$ & $\begin{array}{r}6.2 \\
+\quad 7.2 \\
+\quad 0.1\end{array}$ & $\begin{array}{l}+49 \\
+96 \\
+52\end{array}$ & $\begin{array}{l}+2.7 \\
-2.5 \\
+0.4\end{array}$ & $\begin{array}{r}-494 \\
+\quad 398 \\
-\quad 100\end{array}$ & $\begin{array}{l}+3 \\
-3 \\
-4\end{array}$ & $\begin{array}{r}-1.9 \\
+\quad 5.9 \\
-0.6\end{array}$ & $\begin{array}{l}+5 \\
-262 \\
+270\end{array}$ & $\begin{array}{r}52 \\
+128 \\
+\quad 7\end{array}$ \\
\hline L.D. & $\begin{array}{r}\text { I } \\
\text { II } \\
\text { III }\end{array}$ & $\begin{array}{r}+195 \\
+148 \\
-280\end{array}$ & $\begin{array}{r}+284 \\
+\quad 61 \\
-\quad 130\end{array}$ & $\begin{array}{r}-67 \\
+344 \\
+107\end{array}$ & $\begin{array}{r}7.1 \\
+\quad 9.8 \\
+10.2\end{array}$ & $\begin{array}{l}+76 \\
+133 \\
+188\end{array}$ & $\begin{array}{l}+1.0 \\
+1.9 \\
-2.3\end{array}$ & $\begin{array}{r}+249 \\
+\quad 205 \\
-\quad 274\end{array}$ & $\begin{array}{l}-12 \\
+19 \\
-12\end{array}$ & $\begin{array}{r}-4.8 \\
+8.8 \\
+8.4\end{array}$ & $\begin{array}{l}+35 \\
+144 \\
+144\end{array}$ & $\begin{array}{r}-44 \\
+304 \\
+99\end{array}$ \\
\hline R.J. & II & $\begin{array}{r}+841 \\
+\quad 146 \\
-\quad 236\end{array}$ & $\begin{array}{r}896 \\
-\quad 74 \\
-\quad 136\end{array}$ & $\begin{array}{r}-25 \\
+262 \\
-\quad 25\end{array}$ & $\begin{array}{r}-1.7 \\
-6.1 \\
-10.0\end{array}$ & $\begin{array}{l}+76 \\
+28 \\
-21\end{array}$ & $\begin{array}{l}+4.2 \\
+2.3 \\
-0.4\end{array}$ & $\begin{array}{r}772 \\
-\quad 138 \\
-\quad 174\end{array}$ & $\begin{array}{l}-1 \\
+28 \\
+4\end{array}$ & $\begin{array}{r}3.7 \\
+\quad 2.6 \\
-\quad 8.6\end{array}$ & $\begin{array}{l}+124 \\
-212 \\
+38\end{array}$ & $\begin{array}{r}34 \\
+228 \\
-\quad 9\end{array}$ \\
\hline D.C.(a) & $\begin{array}{r}\text { I } \\
\text { III }\end{array}$ & $\begin{array}{r}655 \\
-\quad 517 \\
-\quad 65\end{array}$ & $\begin{array}{r}730 \\
-\quad 529 \\
+\quad 65\end{array}$ & $\begin{array}{l}-106 \\
+239 \\
+\quad 38\end{array}$ & $\begin{array}{r}-14.2 \\
-\quad 9.7 \\
+\quad 1.0\end{array}$ & $\begin{array}{l}+57 \\
+62 \\
+69\end{array}$ & $\begin{array}{l}+4.1 \\
-3.0 \\
-0.8\end{array}$ & $\begin{array}{r}865 \\
+\quad 657 \\
+\quad 62\end{array}$ & $\begin{array}{r}-17 \\
+3 \\
-5\end{array}$ & $\begin{array}{r}-1.5 \\
-11.0 \\
-0.8\end{array}$ & $\begin{array}{l}+135 \\
-128 \\
-127\end{array}$ & $\begin{array}{l}-86 \\
+262 \\
+45\end{array}$ \\
\hline D.C.(b) & $\begin{array}{r}\text { I } \\
\text { III }\end{array}$ & $\begin{array}{r}892 \\
+\quad 355 \\
+\quad 1\end{array}$ & $\begin{array}{r}798 \\
+\quad 392 \\
+\quad 33\end{array}$ & $\begin{array}{l}-125 \\
+285 \\
+31\end{array}$ & $\begin{array}{r}5.4 \\
+\quad 2.7 \\
+\quad 4.7\end{array}$ & $\begin{array}{l}+146 \\
+135 \\
+125\end{array}$ & $\begin{array}{l}+5.3 \\
+0.2 \\
-0.6\end{array}$ & $\begin{array}{r}909 \\
-\quad 57 \\
+\quad 33\end{array}$ & $\begin{array}{r}-9 \\
+31 \\
-14\end{array}$ & $\begin{array}{r}7.3 \\
+\quad 2.4 \\
+\quad 3.1\end{array}$ & $\begin{array}{l}-111 \\
-335 \\
+66\end{array}$ & $\begin{array}{l}-116 \\
+248 \\
+38\end{array}$ \\
\hline
\end{tabular}

* Balance data are expressed per individual period rather than cumulatively.

+ Corrected for the electrolytes and nitrogen withdrawn in serum samples. Stools, when passed, were formed and not analyzed. Small amounts of vomitus in T.W. and $240 \mathrm{cc}$. in L.D. in the pre-KCl periods were not anaylzed.

$\ddagger$ The $\mathrm{K}$ balances represent changes in excess of the transfers associated with the anabolism and catabolism of proteins. Similar treatment of the Na data does not significantly affect the results. Changes in the NPN have been taken into account in calculating the balance of cell nitrogen (17-19). 
16.4 m.eq. per liter, even though hyperglycemia and acetonuria had disappeared.

3. Potassium: Abnormally high levels of potassium ( 6.5 and 6.7 m.eq. per liter) were noted on admission twice in the same patient, D. C. (a) and D. C. (b) in Table II. In the other six cases the admission values ranged from 3.4 to 5.5 . During the initial period of therapy in.which no potassium was given a dramatic fall of serum potassium to abnormally low levels was observed in patients T. W., L. D., R. J., D. C. (a) and D. C. (b). Though the intermediate points are not recorded the values given are actually the lowest concentrations observed in each patient before the start of $\mathrm{KCl}$ per os or parenterally. Only one of the subjects, R. J., developed obvious muscular paralysis, with inability to move his extremities. As a group, however, the patients were still too ill at the time of most marked hypopotassemia to permit clear differentiation between generalized asthenia and partial paralysis.

The administration of $\mathrm{KCl}$ without exception increased the concentration of serum potassium. The highest recorded level, 5.7 m.eq. per liter, at the end of $\mathrm{KCl}$ therapy was observed in the one patient, D. C. (b), who received the salt intravenously. However, a comparable or even greater increment from 2.8 to 5.6 m.eq. per liter occurred in patient $\mathrm{T}$. W. who took the $\mathrm{KCl}$ per os. It is to be noted that the muscular paralysis of subject $R$. J. cleared promptly following the oral administration of the potassium salt. None of the subjects in this series developed gastrointestinal distress or diarrhea, even though the $\mathrm{KCl}$ was administered in capsules or intravenously as rapidly as $1 \mathrm{gm}$. per hour.

\section{Balances of carbohydrate, nitrogen, and elec- trolytes}

Results of calculations based on the data in Tables I and II have been recorded in Table III. During Period I the external balances indicated that, with but one exception, the patients had utilized or stored about one-half and in one instance as much as 96 per cent of the administered carbohydrate. Since the concentration of blood sugar fell in each patient during this interval, it is obvious that the balance was even more positive. Similarly, in the subsequent two periods of observation the balances of carbohydrate remained predominately positive (Table III).

Without exception during Period I all patients excreted nitrogen in urine in excess of the nitrogen intake (Table III). A considerable portion of this negative balance, however, is assignable to a decrease in the elevated nonprotein nitrogen usually present on admission. Even when this factor has been included in the calculation of the nitrogen balance, six of the eight patients were losing cell nitrogen in Period I (Table III). During the $\mathrm{KCl}$ and post- $\mathrm{KCl}$ periods, when the patients were taking milk, the trend was reversed and the balances of cell nitrogen, with but two significant exceptions, became positive.

In so far as the balances of electrolytes are concerned during the pre- $\mathrm{KCl}$ period, all patients retained large amounts of chloride and sodium. While $\mathrm{KCl}$ was being administered, and in the subsequent interval the external balances of sodium and of chloride were more often negative than positive (Table III). However, not one of the negative balances was of sufficient magnitude to cancel entirely the earlier retention of sodium or chloride. The largest positive balances of sodium and of chloride, more than 1500 m.eq. of each ion for the three periods, were recorded in T.W., even though this patient was admitted with normal concentrations of sodium and chloride. This finding is to be contrasted with the relatively small positive balances of these ions in patient L. D. despite initial hypochloremia and hyponatremia. It should be emphasized, however, that irrespective of the initial concentrations of sodium and chloride in the serum all patients retained these two electrolytes in greater or lesser proportion. Again, as in the interpretation of the positive balances of extracellular water, this can be taken as evidence of replacement of deficits, but it is possible that some of it represents overtreatment. The retained sodium was disparately distributed between the extracellular and cellular fluid. Most of it, and frequently all, remained in the extracellular phase (Table III).

In contrast to the positive balances of sodium, all but one patient lost considerable quantities of body potassium during the first period of treatment. This one patient, T. W., had received, however, a moderate amount of potassium during this interval. During the second period of ther- 
apy in which $\mathrm{KCl}$ was ingested or injected the patients retained, as recorded in Table III under "External Balance," 43 to 92 per cent of the administered potassium. The largest positive external balance was 450 m.eq. in the first case recorded, an average of $7.4 \mathrm{~m}$.eq. per $\mathrm{kgm}$. of body weight. An even greater retention in proportion to body weight, 9.0 m.eq. per $\mathrm{kgm}$., was observed in patient L. D. It is to be noted that comparable degrees of potassium retention were observed in patient D. C. during two separate admissions in coma irrespective of the route of administration. In the first instance, D. C. (a), the salt was administered orally, and in the second, D. C. (b), intravenously. Furthermore, the per kilogram retention of potassium given parenterally in this subject was of the same order of magnitude as that observed on the average in the six other patients treated per os. As might be predicted, the major portion of the retained potassium entered the cellular phase (Table III). The cell balances of potassium during the second period, corrected for the intracellular balances of nitrogen, ranged from +98 to +406 m.eq. In some of the experiments sodium left the cells as potassium entered, but this was by no means an invariable finding. The failure to observe reciprocal exchanges of these two ions more often may have been related in part to the lag in the extrusion of sodium reported by Conway and Hingerty following replacement of experimentally induced cell potassium deficits (27).

Even with these large positive balances of potassium it is not certain that the deficits had been completely corrected in all patients. As a matter of fact, in the third period, during which the intake was limited to milk and water, only one of the eight patients developed negative balances of cell potassium in excess of nitrogen. The others were still retaining a part or all of the potassium available to them in the milk ration.

\section{DISCUSSION}

The electrolyte, nitrogen, and carbohydrate studies in these patients again emphasize that considerable amounts of body constituents are lost during diabetic coma. The losses of body water, of extracellular electrolytes, of cell nitrogen, and of carbohydrate have been recognized and defined $(25,26)$. The striking retention of potas- sium administered to this series of patients points to the existence of concomitant deficits of this cation in the body cells. Such an interpretation is supported by the experiments of Tarail and Elkinton which showed that amounts of potassium as great as those employed in some of our studies were not retained in the body when given by mouth to healthy adults (28). Presumably such subjects do not have potassium deficits and hence the administered potassium is promptly excreted. Diabetic patients in acidosis or coma are, however, depleted of potassium. Several mechanisms appear to be involved in the development of this negative balance. It is obvious, for example, that patients in diabetic acidosis or coma are in negative nitrogen balance. This breakdown of tissue releases potassium bound to protein of cells (17). Similarly, potassium laid down with glycogen in the liver (29) is released from the cells during deglycogenation. These two processes, however, can account for only a small portion of the potassium deficit. Most of the deficit must represent, therefore, a decrease in the cell potassium present in excess of the nitrogen there. Several factors probably contribute to this loss of cell base. First, it is known that extracellular dehydration, per se, is associated with movements of potassium and of water out of the cells (17). Secondly, it has been shown that interruption of carbohydrate metabolism in the blood cell in vitro, either by refrigeration, exhaustion of glucose stores, or by addition of an inhibitor such as fluoride, is associated with a pouring out of cell potassium (30). Finally, the evidence to date suggests that as long as urine is being elaborated it contains potassium. This appears to be true even though deficits of cell potassium, and even extracellular hypopotassemia, are present $(21,28)$. Hence, with the diuresis characteristic of almost all patients in coma considerable amounts of potassium are lost. At present it is not clear to which of these mechanisms the major portion of the potassium deficit is to be ascribed.

The hypopotassemia of extracellular fluid which develops during treatment on a potassium-free regimen noted by other workers and by us stems from a number of sources. It is obvious from our data that it results in part from an expansion of body water with the administration of fluids, 
and in part from a continued loss of potassium in urine. The negative balances of cell potassium recorded during the first period of therapy in seven of the eight patients exclude the possibility that reentry of this ion into cells played any significant role in the decrease in serum potassium. This does not mean, of course, that no potassium was deposited in the liver with reglycogenation, nor that none entered other cells. It merely indicates that these must have been subsidiary processes. Furthermore, the negative balances of potassium cannot be explained away as manifestations of transfers of chloride into cells. Such a movement of the reference ion could not cancel the negative cell balances, since even large alterations of the chloride space could account for only a few milliequivalents of potassium.

During the administration of potassium salts the major portion of the cation entered the cells. Only a small amount of it was laid down with nitrogen. There was no significant urinary loss of previously retained potassium in the post- $\mathrm{KCl}$ periods. As a matter of fact, in five of the experiments more potassium entered the cells. On the whole a smaller proportion of the administered potassium was retained during Period III suggesting that in the majority of the patients cell concentrations of this ion were completely or almost completely restored. It should be emphasized of course that the possibility that the potassium administered orally was incompletely absorbed cannot be excluded. Naturally this would alter the magnitude of the exchanges. However, the findings in control studies (28), and the absence of frequent or diarrheal stools in these patients, suggest that absorption was essentially complete. This is further supported by the finding that quite comparable data were obtained when $\mathrm{KCl}$ was given intravenously.

It is to be noted that positive cell balances of both potassium and sodium were recorded in patients who were admitted with essentially normal serum levels of these ions. These instances should again serve to emphasize the fact that the presence of normal concentrations of any particular electrolyte cannot be interpreted as evidence that the total amount is intact (31). This is of obvious importance in planning replacement therapy.

The physiological significance of these extensive potassium deficits can be as yet partially and only indirectly evaluated. It is known, of course, that muscular paralysis and abnormally low levels of extracellular potassium frequently coexist (1, $2,32-34)$. This is not, however, an invariable association, since paralysis can occur with normal serum concentrations of potassium (35) and our own data indicate that pronounced hypopotassemia can occur without evident paralysis.

At present only analogies can be drawn as to possible deleterious effects of these deficits of intracellular potassium. It has been shown, for example, that the depletion of cellular potassium produced by over-dosage with desoxycorticosterone acetate or by restriction of potassium intake is associated with degenerative changes in the myocardium $(36,37)$. In this respect it is of interest that in our series patient T. W., 26 years of age and previously well, had on admission a grossly abnormal electrocardiogram, characterized by markedly inverted $T$ waves. These changes compatible with myocardial damage were still present one month later, and cleared only after an additional month of convalescence. It may have been more than chance, therefore, that this occurred in the patient who apparently had developed the greatest deficits prior to therapy.

No adequate statistics are yet available as to whether replacement of potassium deficits may mitigate the considerable mortality still associated with diabetic acidosis and coma $(26,38)$. The favorable results of Govan and Darrow in decreasing the fatality rate of infantile diarrhea by means of parenteral and oral potassium therapy suggest that a similar beneficial response may be expected in diabetic coma (39). In testing this form of therapy, however, unremitting care must be taken to avoid deaths from potassium poisoning $(40,41)$. At present it would seem reasonable, therefore, to limit the administration of potassium salts to the oral route, or to give only dilute solutions intravenously. An adequate urine volume and constant electrocardiographic surveillance are essential.

\section{SUMMARY AND CONCLUSIONS}

Patients recovering from diabetic acidosis or coma retained considerable amounts of potassium administered as $\mathrm{KCl}$, in addition to water, sodium, chloride, carbohydrate, and nitrogen. Comparable positive balances of this cation were re- 
corded in one subject during two separate admissions, in one of which $\mathrm{KCl}$ was given by mouth and in the other intravenously. In every study potassium entered cells far in excess of amounts which could be ascribed to changes in cell protein. The possible physiological significance of these findings has been discussed.

\section{ACKNOWLEDGMENT}

The authors wish to acknowledge their indebtedness to Miss J. Kruman, R.N. and Miss D. Hoehl, R.N. and their assistants, to Miss M. Freedman and her staff of technicians, and to the internes and residents of the two hospitals. Without their help this study would not have been possible.

\section{BIBLIOGRAPHY}

1. Holler, J. W., Potassium deficiency occurring during the treatment of diabetic acidosis. J. A. M. A., 1946, 131, 1186.

2. Nicholson, W. M., and Branning, W. S., Potassium deficiency in diabetic acidosis. J. A. M. A., 1947, $134,1292$.

3. Martin, H. E., and Wertman, M., Serum potassium, magnesium, and calcium levels in diabetic acidosis. J. Clin. Invest., 1947, 26, 217.

4. Guest, G. M., and Rapoport, S., Electrolytes of blood plasma and cells in diabetic acidosis and during recovery. Proc. Am. Diabet. A., 1947, 7, 97.

5. Butler, A. M., Talbot, N. B., Burnett, C. H., Stanbury, J. B., and MacLachlan, E. A., Metabolic studies in diabetic coma. Tr. A. Am. Physicians, 1947, 60, 102.

6. Peters, J. P., and Van Slyke, D. D., Quantitative Clinical Chemistry. Vol. II. Methods. Williams and Wilkins, Baltimore, 1932.

7. Somogyi, M., A method for the preparation of blood filtrates for the determination of sugar. J. Biol. Chem., 1930, 86, 655.

8. Benedict, S. R., The estimation of sugar in blood and normal urine. J. Biol. Chem., 1926, 68, 759.

9. Van Slyke, D. D., and Neill, J. M., The determination of gases in blood and other solutions by vacuum extraction and manometric measurement. I. J. Biol. Chem., 1924, 61, 523.

10. Hald, P. M., The flame photometer for the measurement of sodium and potassium in biological materials. J. Biol. Chem., 1947, 167, 499.

11. Quashnock, J. M., Gas pressure regulation in flame photometry. Federation Proc., 1948, 7, 179.

12. Eisenman, A. J., Mackenzie, L. B., and Peters, J. P., Protein and water of serum and cells of human blood, with a note on the measurement of red blood cell volume. J. Biol. Chem., 1936, 116, 33.

13. Sodium and Potassium Analyses of Foods and Waters. Mead Johnson and Company, Evansville, Indiana, 1947.
14. Shohl, A. T., Mineral Metabolism. Reinhold Publishing Corp., New York, 1939.

15. Jeffery, W. H., Note on the Volhard-Harvey method for the estimation of chlorides in urine. J. Lab. \& Clin. Med., 1927, 13, 687.

16. Sumner, J. B., A more specific reagent for the determination of sugar in urine. J. Biol. Chem., 1925, 65, 393.

17. Elkinton, J. R., and Winkler, A. W., Transfers of intracellular potassium in experimental dehydration. J. Clin. Invest., 1944, 23, 93.

18. Elkinton, J. R., Winkler, A. W., and Danowski, T.S., Transfers of cell sodium and potassium in experimental and clinical conditions. J. Clin. Invest., 1948, 27, 74.

19. Darrow, D. C., The retention of electrolyte during recovery from severe dehydration due to diarrhea. J. Pediat., 1946, 28, 515.

20. Elkinton, J. R., The volume of distribution of mannitol as a measure of the volume of extracellular fluid, with a study of the mannitol method. J. Clin. Invest., 1947, 26, 1088.

21. Danowski, T. S., Unpublished data.

22. Elkinton, J. R., Danowski, T. S., and Winkler, A. W., Hemodynamic changes in salt depletion and in dehydration. J. Clin. Invest., 1946, 25, 120.

23. Danowski, T. S., Winkler, A. W., and Elkinton, J. R., Biochemical and hemodynamic changes following the subcutaneous injection of glucose solution. J. Clin. Invest., 1947, 26, 887.

24. Hald, P. M., Heinsen, A. J., and Peters, J. P., The estimation of serum sodium from bicarbonate plus chloride. J. Clin. Invest., 1947, 26, 983.

25. Peters, J. P., Kydd, D. M., Eisenman, A. J., and Hald, P. M., The nature of diabetic acidosis. J. Clin. Invest., 1933, 12, 377.

26. Danowski, T. S., Winkler, A. W., and Peters, J. P., Salt depletion, peripheral vascular collapse, and the treatment of diabetic acidosis. Yale J. Biol. Med., 1946, 18, 405.

27. Conway, E. J., and Hingerty, D., Relations between potassium and sodium levels in mammalian muscle and blood plasma. Biochem. J., 1948, 42, 372.

28. Tarail, R., and Elkinton, J. R., Potassium deficiency and the role of the kidney in its production. $\mathrm{J}$. Clin. Invest., 1948, 27, 557; 1949, 28, 99.

29. Fenn, W. O., The deposition of potassium and phosphate with glycogen in rat livers. J. Biol. Chem., 1939, 128, 297.

30. Danowski, T. S., The transfer of potassium across the human blood cell membrane. J. Biol. Chem., 1941, 139, 693.

31. Elkinton, J. R., Winkler, A. W., and Danowski, T. S., The importance of volume and of tonicity in salt depletion shock. J. Clin. Invest., 1947, 27, 1002.

32. Danowski, T. S., Elkinton, J. R., Burrows, B. A., and Winkler, A. W., Exchanges of sodium and potassium in familial periodic paralysis. J. Clin. Invest., 1948, 27, 65. 
33. Ferrebee, J. W., Parker, D., Carnes, W. H., Gerity, M. K., Atchley, D. W., and Loeb, R. F., Certain effects of desoxycorticosterone; the development of "diabetes insipidus" and the replacement of muscle potassium by sodium in normal dogs. Am. J. Physiol., 1941, 135, 230.

34. Brown, M. R., Currens, J. H., and Marchand, J. F., Muscular paralysis and electrocardiographic abnormalities resulting from potassium loss in chronic nephritis. J. A. M. A., 1944, 124, 545.

35. Talbott, J. H., Periodic paralysis; a clinical syndrome. Medicine, 1941, 20, 85.

36. Darrow, D. C., and Miller, H. C., The production of cardiac lesions by repeated injections of desoxycorticosterone acetate. J. Clin. Invest., 1942, 21, 601.

37. Miller, H. C., and Darrow, D. C., Relation of muscle electrolyte to alterations in serum potassium and to the toxic effects of injected potassium chloride. Am. J: Physiol., 1940, 130, 747.

38. Joslin, E. P., Root, H. F., White, P., Marble, A., and Bailey, C. C., Treatment of Diabetes Mellitus. Lea \& Febiger, Philadelphia. 8th edition, 1946.

39. Govan, C. D., Jr., and Darrow, D. C., The use of potassium chloride in the treatment of dehydration of diarrhea in infants. J. Pediat., 1946, 28, 541.

40. Winkler, A. W., Hoff, H. E., and Smith, P. K., Electrocardiographic changes and concentration of potassium in serum following intravenous injection of potassium chloride. Am. J. Physiol., 1938, 124, 478.

41. Govan, C. D., Jr., and Weiseth, W. M., Potassium intoxication. Report of an infant surviving a serum potassium level of 12.27 millimoles per liter. J. Pediat., 1946, 28, 550. 